\title{
ANALISIS KEBIJAKAN PEMERINTAH TERHADAP KASUS COVID-19 DI BALI MENGGUNAKAN MODEL DERET WAKTU DENGAN FAKTOR INTERVENSI
}

\author{
NURFITRI IMRO'AH ${ }^{a}$, NUR'AINUL MIFTAHUL HUDA $^{b *}$ \\ ${ }^{a}$ Program Studi Statistika, Universitas Tanjungpura, Pontianak, Indonesia, ${ }^{b}$ Program Studi \\ Matematika, Universitas Tanjungpura, Pontianak, Indonesia, \\ email : nurfitriimroah@math.untan.ac.id,nurainul@fmipa.untan.ac.id
}

\begin{abstract}
Abstrak. Kebijakan mengenai kewajiban pelaku perjalanan domestik yang datang ke Bali untuk menunjukkan hasil negatif tes swab Polymerase Chain Reaction (PCR) merupakan salah satu bentuk intervensi dalam menekan banyaknya penambahan kasus positif Coronavirus Disease 2019 (Covid-19) di Bali. Penelitian ini menggunakan model deret waktu dengan faktor intervensi dalam menganalisis dampak setelah dikeluarkannya kebijakan tersebut. Selain itu, penelitian ini juga memprediksi banyaknya kasus Covid-19 di Bali mulai 29 - 31 Maret 2021. Hasil dari penelitian ini menunjukkan bahwa kebijakan yang dikeluarkan oleh Pemerintah Provinsi Bali merupakan salah satu langkah tepat dalam menangani penambahan kasus harian positif Covid-19 di Bali. Hal itu terlihat dari penurunan banyaknya kasus positif di Bali hingga akhir Maret 2021.
\end{abstract}

Kata Kunci: Covid-19, Kebijakan, Deret waktu, Intervensi

\section{Pendahuluan}

Bali adalah salah satu pulau ternama di Indonesia dengan luas wilayah $5.780,06 \mathrm{~km}^{2}$, atau sekitar 0,29\% dari total wilayah Indonesia. Provinsi Bali tidak dapat dipisahkan dari pariwisata. Perpaduan alam yang indah dengan budaya yang mem- pesona menjadi daya tarik bagi wisatawan domestik maupun mancanegara untuk berkunjung ke pulau ini. Oleh karena itu, dapat dikatakan bahwa perekonomian provinsi ini sangat bergantung pada sektor pariwisata, yaitu mencapai $52 \%$ [1]. Hampir setiap tahun, sektor pariwisata menyumbang sekitar 27 triliun rupiah bagi perekonomian Bali. Nominal kontribusi sektor ini menempati urutan keempat terbesar setelah DKI Jakarta, Jawa Timur dan Jawa Barat.

Pada tahun 2016 jumlah wisatawan mancanegara yang datang ke Bali tercatat sebesar 4,927 juta dan selalu meningkat setiap tahunnya hingga tahun 2019 (sebanyak 6,275 juta). Namun jumlah tersebut menurun drastis pada tahun 2020 (sebanyak 1,069 juta). Dimulai pada bulan Maret (sekitar 167 ribu), sedangkan

${ }^{*}$ penulis korespondensi 
dalam kondisi normal sekitar 400 ribu. Begitu juga pada April lalu, turis asing yang berkunjung ke Bali hanya sekitar 379 orang. Bahkan pada September 2020, hanya delapan turis asing yang datang ke Bali [1]. Penurunan drastis tersebut terjadi akibat pandemi Covid-19. Sejak pandemi diumumkan masuk ke Indonesia pada Maret 2020 dan Bali pada 11 Maret 2020 (ditandai dengan meninggalnya pasien Covid-19 yang selanjutnya terdata sebagai kasus ke-25 di Indonesia [2], perekonomian di Bali yang bergerak di sektor pariwisata telah terhenti. Pada tahun 2020, hampir 50\% hotel telah menutup operasinya. Sedangkan $50 \%$ hotel lainnya rata-rata hanya memiliki tingkat hunian sebesar 5\%. Hal tersebut berdampak pada ribuan pekerja pariwisata yang diberhentikan. Sejak saat itu, pemerintah Provinsi Bali mengeluarkan beberapa kebijakan untuk menangani wabah tersebut. Salah satu kebijakannya adalah Surat Edaran (SE) yang mulai berlaku pada 18 Desember 2020. SE tersebut mengatur bahwa pelaku perjalanan domestik yang datang ke Bali melalui transportasi udara harus menunjukkan hasil negatif untuk tes swab PCR (maksimal $7 \times 24$ jam sebelum keberangkatan). Kebijakan ini merupakan salah satu bentuk intervensi dari pemerintah untuk menekan penambahan kasus positif Covid-19 di Bali. Penelitian ini bertujuan untuk memprediksi jumlah penderita Covid-19 di Bali dengan menambahkan faktor intervensi. Beberapa model deret waktu yang sering digunakan adalah model Autoregressive Integrated Moving Average (ARIMA), fungsi transfer dan model ARIMA dengan faktor intervensi (digunakan pada penelitian ini). Jumlah penderita Covid-19 dari tanggal 18 November 202021 Maret 2021 digunakan sebagai variabel terikat dalam model deret waktu. Sedangkan faktor intervensinya adalah kebijakan mengenai wajib swab PCR untuk pelaku perjalanan domestik ke Bali (mulai 18 Desember 2020). Bagian pertama pada penelitian ini menjelaskan pengenalan Bali dan Covid-19. Gambaran tentang model deret waktu ARIMA selanjutnya dijelaskan di bagian kedua. Selanjutnya model ARIMA dengan faktor intervensi dijelaskan pada bagian ketiga. Sedangkan analisis data dan kesimpulan dikemukakan pada bagian ketiga dan keempat.

\section{Landasan Teori}

Misalkan barisan peubah acak $Z_{t}$ mengikuti proses ARIMA, maka $Z_{t}$ dapat didefinisikan sebagai berikut [3]:

$$
\varphi_{p}(B)(1 B)^{d} Z_{t}=v_{0}+v_{q}(B) a_{t},
$$

dengan $\varphi_{p}(B)=\left(1 \varphi_{1} B \varphi_{p} B^{p}\right), v_{q}(B)=\left(1 v_{1} B v_{q} B^{q}\right.$, dan $a_{t}$ adalah error pada waktu $t$.

Model pada Persamaan (2.1) disebut sebagai model ARIMA dengan orde $(p, d, q)$, untuk $p, d, q$ secara berturut-turut merupakan orde Auto-regressive, diferensiasi, Moving Average. Model ARIMA merupakan model yang digunakan untuk data stasioner dengan tiga tahapan utama sebagai berikut [4].

(1) Identifikasi orde menggunakan plot Auto-Correlation Function (ACF) dan Partial ACF (PACF).

(2) Estimasi parameter menggunakan metode kuadrat terkecil dan Maximum Likelihood Estimation. 
(3) Uji diagnostik yang terdiri dari uji kebebasan dan kenormalan residual.

Setelah tiga tahapan utama tersebut dilakukan, maka didapat model terbaik yang selanjutnya dijadikan acuan untuk prediksi $h$ waktu mendatang.

\section{Model ARIMA dengan Faktor Intervensi}

Model deret waktu dengan faktor intervensi memiliki dua tipe, yaitu step function $S_{t}^{(T)}$ dan pulse function $P_{t}^{(T)}$. Step function merupakan intervensi yang terjadi pada waktu $T$ dan dampak dari intervensi tersebut berkelanjutan. Sedangkan pulse function merupakan intervensi yang hanya berdampak pada periode terjadinya intervensi yaitu ketika $t=T$ atau setelah $t=T$. Kedua tipe intervensi tersebut didefinisikan sebagai berikut [3].

$$
\begin{aligned}
S_{t}^{(T)} & =\left\{\begin{array}{l}
0, t<T, \\
1, t \geq T,
\end{array}\right. \\
P_{t}^{(T)} & =\left\{\begin{array}{l}
0, t \neq T, \\
1, t=T,
\end{array}\right.
\end{aligned}
$$

Dengan kata lain, jika step function terdiferensiasi, maka diperoleh pulse function sebagai berikut [5].

$$
S_{t}^{(T)}-S_{t-1}^{(T)}=(1 B) S_{t}^{(T)}=P_{t}^{(T)} .
$$

Hal ini berarti model dengan step function atau pulse function sebagai faktor intervensi dapat direpresentasikan dengan baik. Berikut ini merupakan beberapa dampak dari intervensi yang sering muncul.

(1) Dampak intervensi yang konstan dirasakan selama $b$ periode setelah intervensi. Pada step function, intervensi akan terus berdampak secara konstan sebesar $\omega$ atau dapat dituliskan dengan

$$
\omega B^{b} S_{t}^{(T)}
$$

Sedangkan untuk pulse function, intervensi berdampak sebesar $\omega$ hanya saat waktu $T$ atau dapat dituliskan dengan

$$
\omega B^{b} P_{t}^{(T)} \text {. }
$$

(2) Dampak intervensi dirasakan selama $b$ periode setelah intervensi, tetapi efek yang dihasilkan bersifat gradual [6]. Pada step function, intervensi berdampak secara gradual kenaikan atau penurunannya hingga kekonstanan efeknya tercapai. Efeknya dapat didefinisikan dengan

$$
\frac{\omega B^{b}}{(1-\delta B)} S_{t}^{(T)}
$$

Sementara pada pulse function, intervensi memiliki dampak yang gradual, tetapi menghasilkan dampak yang konvergen ke nol atau akan berakhir pada waktu tertentu. Dampak tersebut dapat didefinisikan sebagai

dengan $0 \geq \delta \geq 1$

$$
\frac{\omega B^{b}}{(1-\delta B)} P_{t}^{(T)}
$$


Model umum deret waktu $A R I M A(p, d, q)$ dengan faktor intervensi diberikan sebagai berikut [7]:

$$
Z_{t}=N_{t}+f_{t}
$$

dengan

$$
f_{t}=\frac{\omega_{c}(B)}{\delta_{r}(B)} B^{b} I_{t}^{(T)}
$$

dan $N_{t}$ merupakan model deret waktu sebelum intervensi ditambahkan, $\omega_{c}(B)=$ $1-\omega_{1} B \cdots-\omega_{c} B^{c}, \delta_{r}(B)=1-\delta_{1} B \cdots-\delta_{r} B^{r}, I_{t}^{(T)}$ merupakan faktor intervensi, dan $B$ merupakan Backshift operator.

\section{Analisis Data}

Penelitian ini menggunakan banyaknya kasus baru harian Covid-19 dari 18 November 202021 Maret 2021 sebagai variabel terikat yang diperoleh dari Badan Nasional Penanggulangan Bencana (BNPB) [7]. Jumlah observasi sebanyak 124 kasus. Pada proses pemodelan, data dibagi menjadi dua yaitu data in-sample (digunakan untuk melihat akurasi model yang diperoleh) dan out-sample (digunakan untuk melihat akurasi prediksi berdasarkan model yang diperoleh). Pemerintah Provinsi Bali mengeluarkan Surat Edaran yang mengatur bahwa pelaku perjalanan domestik yang datang ke Bali menggunakan transportasi udara wajib menunjukkan hasil negatif tes Swab PCR. Peraturan ini berlaku mulai 18 Desember 2020 sampai dengan 8 Januari 2021 dan akan terus diperpanjang. Kebijakan mengenai Swab PCR digunakan sebagai faktor intervensi dalam penelitian ini. Oleh karena itu, data insample dibagi menjadi dua bagian yaitu pra-intervensi (18 November 202017 Desember 2020) dan pasca-intervensi (18 Desember 202021 Maret 2021). Statistik deskriptif data disajikan pada Tabel 1 .

\begin{tabular}{|c|c|c|c|c|c|}
\hline & Minimum & Maksimum & Rataan & Median & Variansi \\
\hline Data Keseluruhan & 0,00 & 542,00 & 203,72 & 182,50 & $12.323,52$ \\
\hline Pre-Intervensi & 61,00 & 230,00 & 105,33 & 100,50 & $1.369,06$ \\
\hline Pasca-Intervensi & 0,00 & 542,00 & 235,12 & 229,00 & $11.753,01$ \\
\hline
\end{tabular}

Tabel 1. Statistik Deskriptif dari 30 Pengamatan pada Pra-intervensi, 94 Pengamatan pada Pascaintervensi, dan 124 Pengamatan sebagai Data Keseluruhan

Intervensi yang diterapkan di Bali diharapkan dapat menekan jumlah penderita baru Covid-19. Namun, rata-rata jumlah kasus meningkat dari 105,33 menjadi 235,12 (lihat Tabel 1). Indikasi awal dari fenomena ini adalah kebijakan tersebut tidak berdampak pada jumlah penderita baru Covid-19 di Bali. Jumlah kasus baru tertinggi terjadi setelah intervensi dilaksanakan, pada 26 Januari 2021 sebanyak 542 kasus. Secara bersamaan pada tanggal tersebut, Bali menerapkan perpanjangan penerapan pembatasan kegiatan masyarakat, yang disebut dengan PPKM. Pelaksanaannya dilakukan berdasarkan pemantauan dan evaluasi pelaksanaan PPKM pertama, 1125 Januari 2021. Kasus baru ini tercatat nol kasus, (14 
Maret 2021), namun meningkat pada hari-hari berikutnya. Gambar 1(a) berikut menyajikan banyaknya kasus harian baru Covid-19 di Bali secara rinci. Berdasarkan
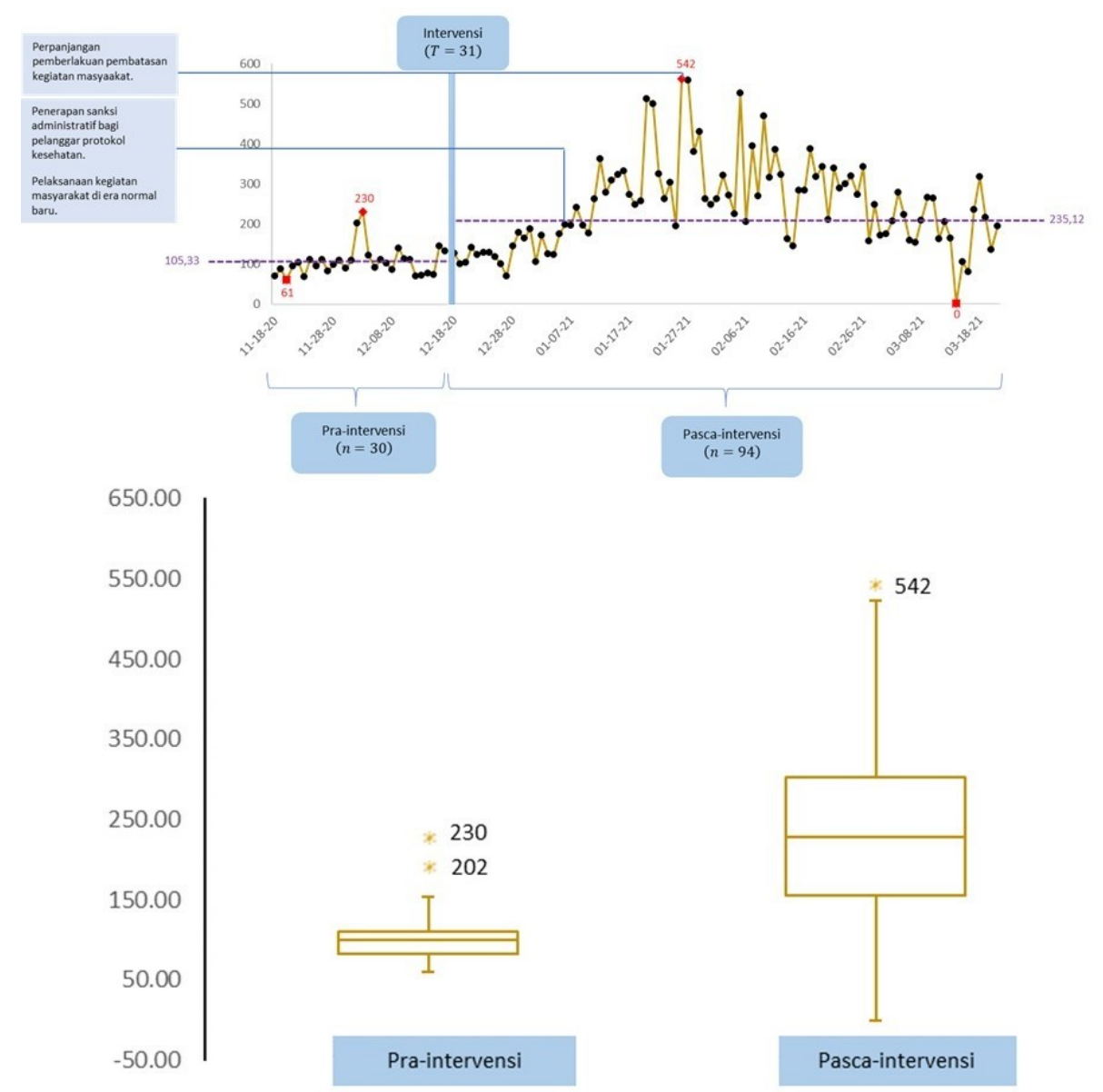

Gambar 1. Gambaran Data Covid-19 (a) Plot Deret Waktu (b) Boxplot untuk Pra-Intervensi dan Pasca-Intervensi

boxplot (lihat Gambar 1(b)), terdapat beberapa pencilan baik pada pra-intervensi maupun pasca-intervensi. Hal ini berarti adanya kenaikan yang signifikan terhadap pertambahan kasus harian Covid-19 di Bali.

\subsection{Pemodelan Data}

Pada model ini, kebijakan mengenai pelaku perjalanan domestik yang datang ke Bali menggunakan transportasi udara harus menunjukkan hasil negatif dari tes swab PCR yang digunakan sebagai faktor intervensi. Langkah awal pemodelan data adalah memodelkan data pra-intervensi menggunakan model $A R I M A(p, d, q)$. Plot data pra-intervensi disajikan pada Gambar 2 berikut. Data pra-intervensi dikatakan 


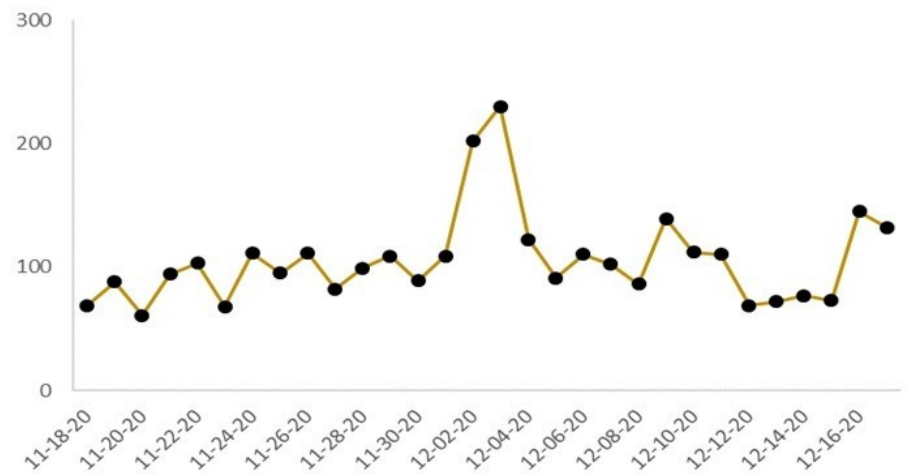

Gambar 2. Plot Data dari Banyaknya Kasus Covid-19 di Bali Pra-Intervensi

stasioner karena memiliki rataan dan varians yang konstan (lihat Gambar 2).

Selanjutnya plot ACF dan PACF akan ditinjau untuk mengidentifikasi orde pada model $A R I M A(p, d, q)$. Berdasarkan Gambar 3, terdapat tiga kemungkinan model yaitu $\operatorname{ARIMA}(0,0,2), \operatorname{ARIMA}(1,0,0)$ dan $\operatorname{ARIMA}(1,0,2)$ dengan masing-masing parameter pada ketiga model tersebut dapat dilihat pada Tabel 2. Parameter tersebut diperoleh dengan menggunakan metode Kuadrat Terkecil.
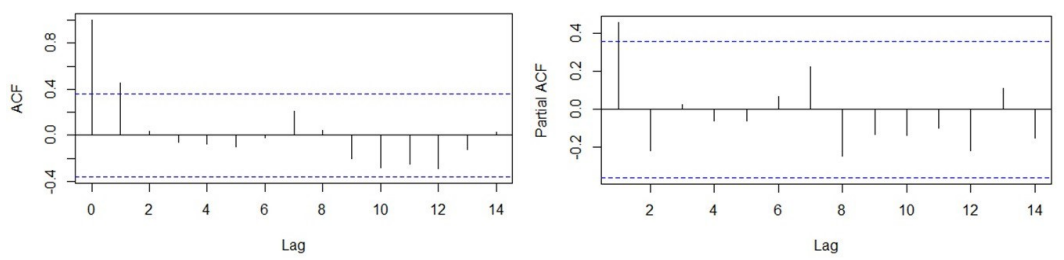

Gambar 3. Plot (a) Auto-Correlation Function (ACF), dan (b) Partial ACF

\begin{tabular}{|c|c|c|c|c|c|}
\hline Model & Rataan & $\phi$ & $\theta_{1}$ & $\theta_{2}$ & AIC \\
\hline ARIMA(0,0,2) & 104,6754 & - & 0,5762 & 0,0839 & 300,2100 \\
\hline ARIMA(1,0,0) & 105,0702 & 0,4634 & - & - & $\mathbf{2 9 9 , 6 4 0 0}$ \\
\hline ARIMA(1,0,2) & 104,6626 & 0,0396 & 0,6153 & 0,1062 & 302,2100 \\
\hline
\end{tabular}

Tabel 2. Parameter Model dan AIC dari Model $A R I M A(p, d, q)$ sebelum Intervensi

Teks tebal pada Tabel 2 merupakan nilai AIC terkecil sehingga uji diagnostik residual diterapkan pada model ARIMA $(1,0,0)$. Plot terkait residual model tersebut dapat dilihat pada Gambar 4.

Pada Gambar 4, residual model ARIMA(1,0,0) saling bebas terhadap lag waktu sehingga asumsi kebebasan residual terpenuhi. Gambar 4 juga menunjukkan plot p-value untuk uji kenormalan residual (Ljung-Box). Nilai $p$-value untuk setiap lag 


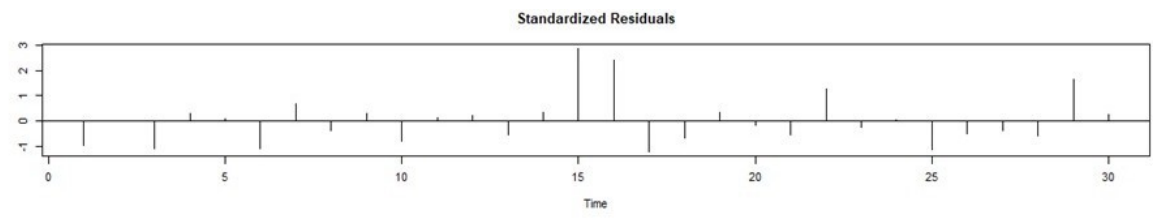

ACF of Residuals
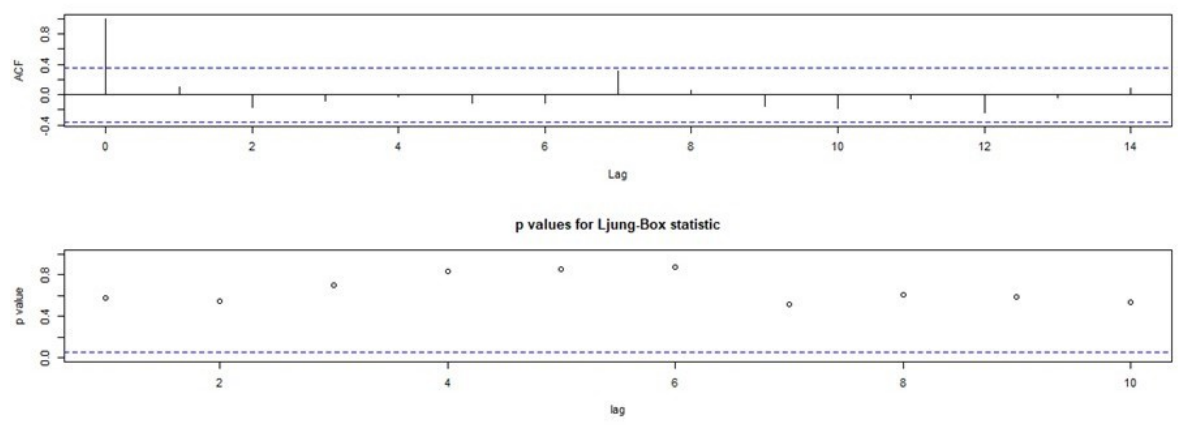

Gambar 4. Plot Residual dari Model ARIMA(1,0,0)

lebih besar dari taraf signifikansi 5\%. Hal ini menunjukkan bahwa residual juga memenuhi asumsi kenormalan. Dengan demikian dapat disimpulkan bahwa model $\operatorname{ARIMA}(1,0,0)$ merupakan model terbaik dari data pra-intervensi, yaitu

$$
Y_{t}=105,0702+0,4634 Y_{t 1}+e_{t}
$$

dengan $Y_{t}$ adalah banyaknya kasus harian baru pada waktu $t$ dan $e_{t}$ merupakan error pada waktu $t$ untuk $t=1,2, \cdots, 30$.

Selanjutnya model pada Persamaan (4.1) ditambahkan dengan faktor intervensi. Dalam hal ini digunakan step function karena diduga efek dari intervensi yang ditimbulkan akan memiliki efek yang berkelanjutan, didefinisikan sebagai berikut

$$
f_{31}(\omega)=\omega B S_{t}^{(31)} .
$$

Berdasarkan Persamaan (3.1), model keseluruhan untuk model deret waktu dengan faktor intervensi dapat dituliskan dengan

$$
Z_{t}=\mu+\phi Z_{t 1}+\omega S_{t-1}^{(31)} \phi \omega S_{t-2}^{(31)}+e_{t} .
$$

Persamaan (4.2) selanjutnya disebut sebagai model deret waktu $\operatorname{ARIMA}(1,0,0)$ dengan faktor intervensi pada waktu $T=31$. Kemudian parameter pada Persamaan (4.2) diestimasi menggunakan metode Kuadrat Terkecil. Hasil dari estimasi tersebut diberikan pada Tabel 3. Dengan demikian, Persamaan (4.2) menjadi

\begin{tabular}{|c|c|c|c|}
\hline Parameter & $\mu$ & $\phi$ & $\omega$ \\
\hline Hasil Estimasi & 47,667 & 0,563 & 19,846 \\
\hline
\end{tabular}

Tabel 3. Estimasi Parameter Model Deret Waktu ARIMA(1,0,0) dengan Faktor Intervensi pada saat $T=31$ 


$$
Z_{t}=47,667+0,563 Z_{t 1} 19,846 S_{t-1}^{(31)}+11,182 S_{t-2}^{(31)}+e_{t} .
$$

Sedangkan efek dari intervensi pada penelitian ini didefinisikan dengan

$$
\text { Effect }= \begin{cases}15,284, T>31 \\ 0, & \text { lainnya. }\end{cases}
$$

Persamaan (4.3) selanjutnya diterapkan pada data in-sample untuk melihat kecocokan hasil estimasi dengan data aktual yang ditunjukkan pada Gambar 5a. Sedangkan Persamaan (4.4) divisualisasikan melalui Gambar 5b. Berdasarkan gambar tersebut terlihat bahwa kebijakan yang dikeluarkan oleh Pemerintah Provinsi Bali memiliki dampak berkelanjutan. Pengaruh intervensi terjadi secara terus menerus sebesar 15,284 kasus (dibulatkan menjadi 15 kasus) untuk $T>31$ (setelah 18 Desember 2020).

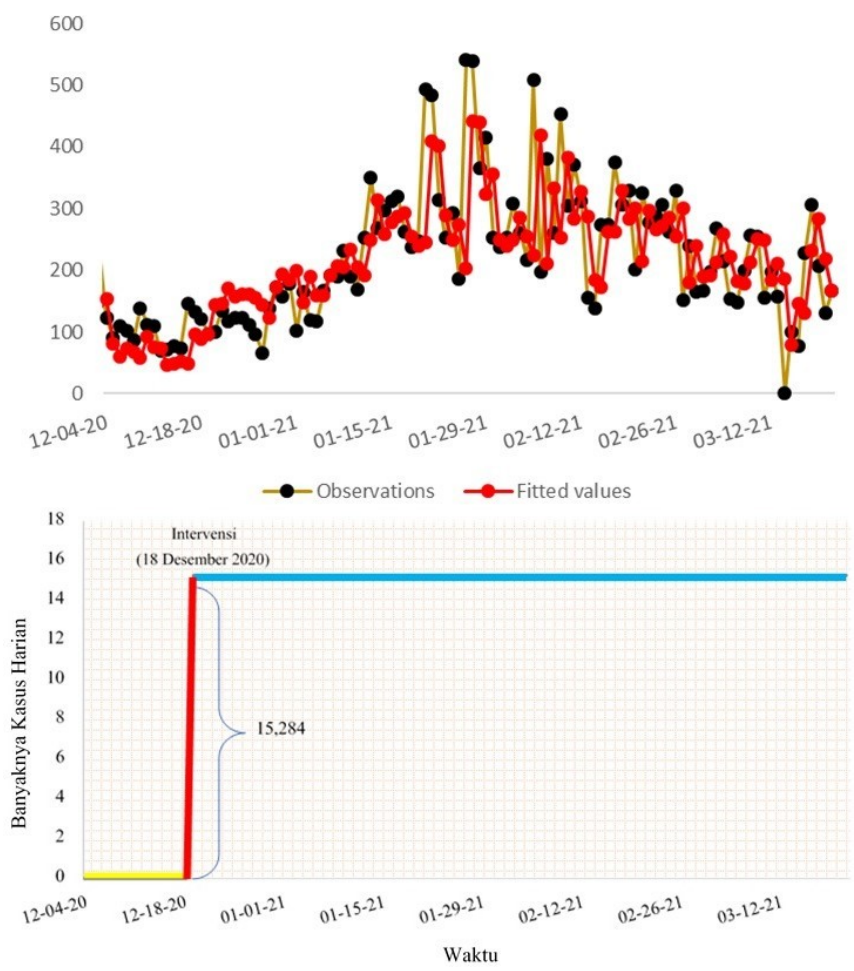

Gambar 5. Plot (a) Kecocokan Hasil Estimasi terhadap Data Aktual, (b) Efek Intervensi. Warna kuning, merah, dan biru berturut-turut menunjukkan efek sebelum intervensi, saat intervensi, dan setelah intervensi

\subsection{Prediksi}

Sebelum memprediksi banyaknya kasus Covid-19 di Bali untuk tiga periode ke depan, model pada Persamaan (4.3) diterapkan untuk data out-sample sebagai ba- 
han pertimbangan keakuratan model. Langkah tersebut dinamakan dengan prediksi data out-sample. Hasil prediksi tersebut disajikan pada Tabel 4 berikut.

\begin{tabular}{|c|c|c|c|}
\hline Waktu & Observasi & Prediksi Data Out-Sample & Absolute Error \\
\hline 22 Maret 2021 & 174,000 & 143,807 & 30,193 \\
\hline 23 Maret 2021 & 182,000 & 176,049 & 5,951 \\
\hline 24 Maret 2021 & 189,000 & 180,557 & 8,443 \\
\hline 25 Maret 2021 & 201,000 & 184,501 & 16,499 \\
\hline 26 Maret 2021 & 178,000 & 191,263 & 13,263 \\
\hline 27 Maret 2021 & 145,000 & 178,303 & 33,303 \\
\hline 28 Maret 2021 & 121,000 & 159,709 & $\mathbf{3 8 , 7 0 9}$ \\
\hline
\end{tabular}

Tabel 4. Prediksi Data Out-Sample menggunakan Model ARIMA(1,0,0) dengan Faktor Intervensi

Teks tebal pada Tabel 4 menunjukkan nilai absolute error terbesar yang terjadi pada 28 Maret 2021, dengan hasil prediksinya jauh berbeda dengan data aslinya. Walaupun demikian, model $\operatorname{ARIMA}(1,0,0)$ dengan faktor intervensi baik digunakan untuk memprediksi beberapa periode mendatang. Hal ini dikarenakan nilai MSE yang dihasilkan pada data out-sample adalah 581,982. Nilai tersebut lebih kecil dari MSE data in-sample yang bernilai 12.815,630. Selanjutnya model $\operatorname{ARIMA}(1,0,0)$ dengan faktor intervensi digunakan untuk prediksi tiga periode berikutnya. Hasilnya menunjukkan bahwa kasus Covid-19 di Bali menurun dari tanggal 29 hingga 31 Maret 2021. Hal tersebut dapat dilihat pada Gambar 6.

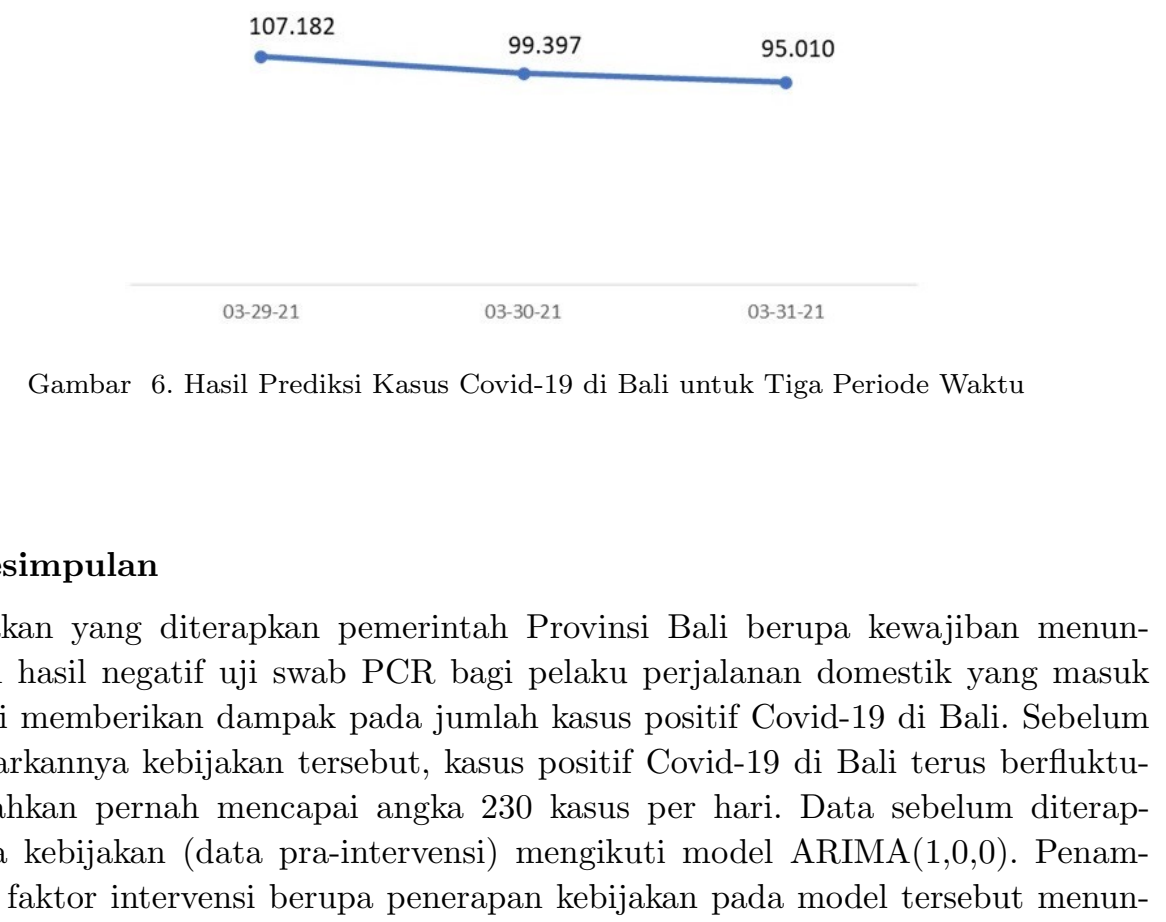

\section{Kesimpulan}

Kebijakan yang diterapkan pemerintah Provinsi Bali berupa kewajiban menunjukkan hasil negatif uji swab PCR bagi pelaku perjalanan domestik yang masuk ke Bali memberikan dampak pada jumlah kasus positif Covid-19 di Bali. Sebelum dikeluarkannya kebijakan tersebut, kasus positif Covid-19 di Bali terus berfluktuasi, bahkan pernah mencapai angka 230 kasus per hari. Data sebelum diterapkannya kebijakan (data pra-intervensi) mengikuti model $\operatorname{ARIMA}(1,0,0)$. Penambahan faktor intervensi berupa penerapan kebijakan pada model tersebut menun- 
jukkan hasil yang lebih baik. Meskipun pada awal penerapan kebijakan, banyaknya kasus masih terus meningkat dan selanjutnya berangsur mengalami penurunan. Dampak yang ditimbulkan setelah diterapkannya kebijakan terjadi secara konstan dan berkelanjutan. Hal ini dapat dilihat dari semakin menurunnya kasus positif di Bali hingga akhir Maret 2021. Selain itu juga dapat dilihat dari nilai MSE yang dihasilkan pada data out-sample jauh lebih kecil daripada MSE data in-sample. Artinya model ARIMA(1,0,0) dengan penambahan faktor intervensi baik digunakan untuk prediksi. Sehingga dapat dikatakan bahwa kebijakan yang dikeluarkan oleh pemerintah Provinsi Bali merupakan salah satu langkah tepat dalam menekan penambahan kasus positif Covid-19 di Bali.

\section{Daftar Pustaka}

[1] Badan Pusat Statistik Indonesia, 2020. Diakses 21 Maret 2021.

[2] Badan Nasional Penanggulangan Bencana, 2021. Diakses 21 Maret 2021.

[3] Wei, W.W.S., 2006, Time Series Analysis: Univariate and Multivariate Methods, Edisi ke-2, Pearson Prentice Hall, New Jersey.

[4] Box, G.E.P., dan Jenkins, G.M., 1976, Time Series Analysis: Forecasting and Control, John Wiley and Son, Inc, New York.

[5] Cryer, J.D. dan Chan, K.S., 2008, Time Series Analysis: With Application in $R$, Edisi ke-2, Springer Science and Business Media, USA.

[6] Sridharan, S., Suncica, V., Siem, Jam, dan Koopman., 2003, Intervention Time Series Analysis of Crime Rates, Journal of Econometrics.

[7] Gilmour, S., Louisa, D., Wayne, H., dan Carolyn D., 2006, Using intervention time series analysis to assess the effects of imperfectly identifiable natural events: a general method and example, Journal of Biomedical, Volume : 16.

[8] Montgomery, D.C., Cheryl, L.J., Murat, Kulachi, 2015, Introduction to Time Series Analysis and Forecasting, John Wiley and Son, Inc, New York. 